\title{
Study on Pyrolysis Characteristics of Bituminous Coals by TGA
}

\author{
Xu Zhice ${ }^{1,2}$ \\ 1 The School of Chemical Engineering. 2 The School of \\ Chemical and Pharmaceutical Engineering \\ 1 Tianjin University. 2 Hebei University of Science and \\ Technology \\ 1 Tianjin, China. 2 Shijiazhuang, China \\ E-mail: xujinghan2004@126.com
}

\author{
Hu Yongqi ${ }^{1,2}$ \\ 1 The School of Chemical Engineering. 2 The School of \\ Chemical and Pharmaceutical Engineering \\ 1 Tianjin University. 2 Hebei University of Science and \\ Technology \\ 1 Tianjin, China. 2 Shijiazhuang, China \\ E-mail: yongqi_h@163.com
}

\author{
Chen Hong \\ Hebei Jiheng (Group) Pharmaceutical Co., Ltd. \\ Hengshui, China \\ E-mail: chenhonggood@ hotmail.com
}

\begin{abstract}
With the economic growth and energy reduction, the prices of anthracite are soaring. Some companies expect to use bituminous coal instead of anthracite for ammonia synthesis. Therefore, in order to find suitable bituminous coals gasification for synthetic ammonia, thermal gravimetric analysis is used to study on the pyrolysis characteristics of $\mathbf{1 5}$ kinds of bituminous coals, and the combustion temperatures start point of the volatile matter and fixed carbon of different bituminous coals in this paper. Comprehensive factors into account, the bituminous coal which is suitable for the separation of volatile matter and fixed carbon is chosed.
\end{abstract}

Keywords-pyrolysis characteristics; thermogravimetric; analysis bituminous coal

\section{INTRODUCTION}

Coal, which is the early earth's solar energy storage, is a valuable resource of organic carbon. It have been several hundred years that human understanding and use of coal. It is not only an important energy, but also the raw materials of metallurgical, chemical, building and other industries. Chemical industry is started with coal chemical, so coal occupies very important position in it. China is rich in coal resources and has larger consumption of coal. Since 1990, the coal consumption of china has been the highest in the world. The overall coal consumption of China accounts for $70 \%$ of the total energy production and consumption [1]. Therefore, the coal which is an important energy, occupies a very important position in our civil economics.

Since 1902, Harbor, the German chemist studied on producing Ammonia directly from nitrogen and hydrogen and applied for a patent in 1908, which was named as "robin method". The process of ammonia synthesis has been developed for a hundred years [2]. However, with the economic growth and energy reduction, the prices of anthracite are soaring. Some companies wanted to use bituminous coal instead of anthracite to make gasification, for bituminous coal's relatively low price. However, the bituminous coal has a high volatile content and in the process of heating will produce the volatile compounds such as methane, which will make the impurities of gas composition increased. The impurities are unfavorable gas in the section of ammonia synthesis, and will affect the subsequent production.

In order to solve this problem, Some companies got a method that the volatile substance should be separated from fixed carbon to reduce the high volatile of bituminous coal. Therefore, the pyrolysis characteristics of bituminous coal should be known. Specifically, the combustion temperature of volatile substance and the combustion temperature of fix carbon should be found separately. Coal research has long history all over the world. There are a lot of researches on Gasification technology, coal pyrolysis studies, activation properties of coal, and coal gasification research etc. Such as, Liu et al. studied the pyrolysis and combustion characteristics of high volatile bituminous coal by Py-FTIR and TGA. The results show that hydrocarbon gases emit a lot during the pyrolysis of high volatile bituminous coal. From the combustion test it was found clearly that the process could be divided into pyrolysis section and combustion section, and the volatiles pyrolysis section was very rapid release, thus revealing the reason that in the combustion process of high volatile sub-bituminous coal it produces a lot of smoke[3]. Seeker et al. observed that the jet shape volatiles were released from the bituminous grains by holographic method and volatile cloud was formed, then smoke particles (about $3 \mu \mathrm{m})$ formed and polymerized [4].

However, there is no research method to find the ignition points and the differences in combustion temperature between volatile substance and fix carbon. In this paper we have studied the pyrolysis characteristics of 15 kinds of bituminous coals, found the combustion temperatures discussed above. These results could provide data for ammonia plants.

\section{RESULTS AND DISCUSSION}

A. Thermal Gravimetric Experiment of Bituminous Coal under Nitrogen Atmosphere

The 15 kinds of bituminous coals were tested by thermal 
gravimetric analysis under nitrogen atmosphere. The resulting moisture and volatile content were shown in Table I . The 15 kinds of bituminous coals was respectively High sulphur rich coal 1.6, Domestic main coke, Hengda fat coal, Kowloon coking coal, Junteng gas fat coal, Luan meager lean coal, Luneng bituminous coal, Lushi gas fat coal, meager lean coal, Shanjiao high sulphur main coke 2.0, Shanjiao high sulphur main coke 1.3, Urat main coke, Xielian coking coal, Sheep canal river lean coal, raw coal.

The gasification reaction of $\mathrm{C}+\mathrm{H}_{2} \mathrm{O} \rightarrow \mathrm{CO}+\mathrm{H}_{2}$, which takes coal as raw material, takes place under high temperature conditions. This needs the heat provided by outside. Volatile matter combustion in bituminous coal is exothermic reaction. It will be a better way of coupling that taking this part of the heat released to the heat required for the gasification reaction. Therefore, knowing the volatile content of a coal sample will be beneficial for coal utilization in ammonia synthesis. Total moisture content of coal into the furnace affects the stability of furnace conditions and coal consumption. The total moisture content of coal into the furnace requires below $6 \%$ [5].

The moisture contents of the 15 kinds of bituminous coals shown in Table. 1 are under 3\%, apart from Xielian coking coal, whose moisture content is slightly higher than $3 \%$. The coal of high volatile content (such as air fat coal) has the long side chain and the high oxygen content. It forms a lot of low boiling point thermally unstable liquid products after thermal decomposition and these liquid products are soon thermal decomposition into gaseous products to escape. Choosing this kind of coal coking can obtain more chemical products, but the abrasion resistance of formed coke is poor and its strength is small. The coals of high volatile content (such as lean coal and meager lean coal) have less side chain and functional groups, and their oxygen contents are low. The chemical products are less during thermal decomposition, forming the coke of poor wear resistance and large blocks. The coals of medium volatile content (such as fat coal and coking coal) have more side chain and functional groups, but their oxygen contents are low. The fat coal can form more liquid product after thermal decomposition and can be refined out the coke of good wear resistance, while the coking coal can produce good wear resistance and higher strength coke. The bituminous coal of different volatile content can be used for different purposes. From our country's coal resources with the characteristics that gas coal and $1 / 3$ coking coal are more, the method of reasonable blending is adopted.

\section{B. Thermal Gravimetric Experiment of Bituminous Coal under Air Atmosphere}

The 15 kinds of bituminous coals were tested by TGA under air atmosphere. The combustion temperature start points of the volatile matter $\left(T_{\text {volatile matter }}\right)$ of the 15 kinds of bituminous coals were shown in Table II.

Coal is a kind of complex polymer compounds and a series of physical and chemical changes takes place when coal is heated in an air atmosphere. From the thermogravimetric curve of bituminous coal measured under the air we can judge the pyrolysis condition of the bituminous coal as the temperature rises. The combustion temperatures start point of the volatile matter is obtained by thermogravimetric fitting program. Different bituminous coal has different volatile combustion temperature. The data shown in Table II indicate the combustion temperatures start points of the volatile matter of the 15 kinds of bituminous coals.

\section{Thermal Gravimetric Experiment of Bituminous Coal Removed Volatiles under Air Atmosphere}

The combustion temperature start points of the fixed carbon $\left(T_{\text {fixed carbon }}\right)$ of the 15 kinds of bituminous coals tested by TGA under air atmosphere were shown in Table III. Before the test, in order to get a fixed carbon for testing, the muffle furnace was used to deal with the volatile matter of the bituminous coals.

After removal of volatiles, fixed carbon observed is mainly powder. Touching the part which was not powder gently with fingers, it would turn into powder or was basically a powder. When the bituminous coal removed volatiles was heated in an air atmosphere, a series of physical and chemical changes took place. The pyrolysis condition of fixed carbon as the temperature rises and the combustion temperature start points of the fixed carbon were obtained from the thermogravimetric curve. The data shown in Table IIIindicate the combustion temperatures start points of the fixed carbon of the 15 kinds of bituminous coals.

The volatile matter in coal is hydrogen, methane and other small molecular substances and a small amount of tar and their burning point is different from fixed carbon. In the case of bituminous coal heated, volatiles and fixed carbon in different temperature ranges will start burning, that there is a certain temperature difference between them.

The greater the difference was, the more easily volatile and fixed carbon separated. That was suitable bituminous coal for synthetic ammonia. Table IV shows the volatile and fixed carbon combustion temperature difference of the 15 kinds of bituminous coals. As shown in Table 4, the order from good to bad for bituminous coal gasification for ammonia synthesis: Hengda fat coal, Domestic main coke, Lushi gas fat coal, Shanjiao high sulphur main coke 1.3, High sulphur rich coal 1.6, Xielian coking coal, Kowloon coking coal, Sheep canal river lean coal, meager lean coal, Urat main coke, Shanjiao high sulphur main coke 2.0, Luneng bituminous coal, Luan meager lean coal, Junteng gas fat coal, raw coal

\section{SUMMARY}

Based on these experiments, the following conclusions were obtained.

1 The moisture and volatile content of the 15 kinds of bituminous coals were tested by thermal gravimetric analysis under nitrogen atmosphere. The most moisture contents of the 15 kinds of bituminous coals are under $3 \%$ and different bituminous coals have different volatile content, which can be used for different purposes.

2 The combustion temperature start points of the volatile matter and the fixed carbon of the 15 kinds of bituminous coals were obtained separately by TGA under air atmosphere. 
Therefore, the temperature difference of volatile and fixed carbon combustion were obtained. The greater the difference was, the more easily volatile and fixed carbon separated. The order from good to bad for bituminous coal gasification for ammonia synthesis was obtained.The most suitable bituminous coal gasification for ammonia synthesis was Hengda fat coal.

\section{REFERENCES}

[1] X. Q. Zhou, X. H. Wang and J. J. Wu, "Study on the pulverized coal combustion characteristic by thermogravimetric differential thermal infrared spectroscopy," The coal conversion, vol. 26, pp. 71, 2003.
[2] C. A. Gurgel Veras, J. A. Saastamoinen, "Overlapping of the devolatilization and char combustion stages in the burning of coa particles."Combustion and Flame. vol. 116, pp. 567-579, 1999.

[3] GB212-91 China National standard, "coal in the determination of volatile content".

[4] W. R. Seeker, C. S. Samuelsen, M. P. Heap, "The thermal decomposition of pulverized coal particles.18th International Symposium on Combustion." Pittsburgh:Pittsburgh University, pp.1213-1215, 1981.

[5] H. Q. Liao, W. Li and C. G. Song, "Mechanism of coal pyrolysis new progress." Coal conversion, vol. 19, pp.1-8, 1996.

TABLEI. MOISTURE AND VOLATILE MATTER CONTENT OF THE 15 KINDS OF BITUMINOUS COALS

\begin{tabular}{|c|c|c|c|c|c|c|c|c|}
\hline & $\begin{array}{c}\text { High sulphur } \\
\text { rich coal 1.6 }\end{array}$ & $\begin{array}{c}\text { Domestic main } \\
\text { coke } \\
\end{array}$ & Hengda fat coal & $\begin{array}{c}\text { Kowloon } \\
\text { coking coal }\end{array}$ & $\begin{array}{c}\text { Junteng gas } \\
\text { fat coal }\end{array}$ & $\begin{array}{c}\text { Luan meager } \\
\text { lean coal }\end{array}$ & $\begin{array}{c}\text { Luneng } \\
\text { bituminous coal }\end{array}$ & $\begin{array}{c}\begin{array}{c}\text { Lushi gas } \\
\text { fat coal }\end{array} \\
\end{array}$ \\
\hline $\begin{array}{c}\text { moisture } \\
\text { content }[\%]\end{array}$ & 1.094 & 1.071 & 1.154 & 0.2429 & 2.679 & 1.242 & 1.398 & 2.977 \\
\hline \multirow[t]{2}{*}{$\begin{array}{c}\text { volatile matter } \\
\text { content [\%] }\end{array}$} & 16.25 & 30.65 & 15.14 & 12.65 & 42.36 & 14.98 & 21.16 & 21.47 \\
\hline & $\begin{array}{c}\text { meager lean } \\
\text { coal }\end{array}$ & $\begin{array}{c}\text { Shanjiao high } \\
\text { sulphur main coke } \\
2.0 \\
\end{array}$ & $\begin{array}{c}\text { Shanjiao high } \\
\text { sulphur main coke } \\
1.3 \\
\end{array}$ & $\begin{array}{l}\text { Urat main } \\
\text { coke }\end{array}$ & $\begin{array}{c}\text { Xielian } \\
\text { coking coal }\end{array}$ & $\begin{array}{l}\text { Sheep canal } \\
\text { river lean coal }\end{array}$ & raw coal & \\
\hline $\begin{array}{c}\text { moisture } \\
\text { content }[\%]\end{array}$ & 0.7755 & 1.742 & 1.449 & 0.9117 & 3.098 & 0.7589 & 2.003 & \\
\hline $\begin{array}{c}\text { volatile matter } \\
\text { content }[\%]\end{array}$ & 23.53 & 24.84 & 27.28 & 36.33 & 20.46 & 18.96 & 30.10 & \\
\hline
\end{tabular}

TABLEII. THE COMBUSTION TEMPERATURE START POINTS OF THE VOLATILE MATTER OF THE 15 KINDS OF BITUMINOUS COALS

\begin{tabular}{|c|c|c|c|c|c|c|c|c|}
\hline & $\begin{array}{l}\text { High sulphur } \\
\text { rich coal } 1.6\end{array}$ & $\begin{array}{c}\text { Domestic main } \\
\text { coke }\end{array}$ & Hengda fat coal & $\begin{array}{l}\text { Kowloon } \\
\text { coking coal }\end{array}$ & $\begin{array}{c}\text { Junteng } \\
\text { gas fat } \\
\text { coal }\end{array}$ & $\begin{array}{l}\text { Luan meager } \\
\text { lean coal }\end{array}$ & $\begin{array}{c}\text { Luneng } \\
\text { bituminous } \\
\text { coal }\end{array}$ & $\begin{array}{c}\text { Lushi } \\
\text { gas fat } \\
\text { coal }\end{array}$ \\
\hline$T_{\text {volatile matter }}\left[{ }^{\circ} \mathrm{C}\right]$ & 451.13 & 450.87 & 431.78 & 469.79 & 432.92 & 510.27 & 454.39 & 411.08 \\
\hline & $\begin{array}{c}\text { meager lean } \\
\text { coal }\end{array}$ & $\begin{array}{c}\text { Shanjiao high } \\
\text { sulphur main } \\
\text { coke } 2.0\end{array}$ & $\begin{array}{l}\text { Shanjiao high } \\
\text { sulphur main } \\
\text { coke } 1.3\end{array}$ & $\begin{array}{l}\text { Urat main } \\
\text { coke }\end{array}$ & $\begin{array}{c}\text { Xielian } \\
\text { coking } \\
\text { coal }\end{array}$ & $\begin{array}{l}\text { Sheep canal } \\
\text { river lean } \\
\text { coal }\end{array}$ & raw coal & \\
\hline$T_{\text {volatile matter }}\left[{ }^{\circ} \mathrm{C}\right]$ & 499.81 & 459.03 & 454.91 & 452.97 & 405.49 & 492.62 & 459.31 & \\
\hline
\end{tabular}

TABLEIII. THE COMBUSTION TEMPERATURE START POINTS OF THE FIXED CARBON OF THE 15 KINDS OF BITUMINOUS COALS

\begin{tabular}{|c|c|c|c|c|c|c|c|c|}
\hline & $\begin{array}{c}\text { High sulphur } \\
\text { rich coal } 1.6\end{array}$ & $\begin{array}{c}\text { Domestic main } \\
\text { coke }\end{array}$ & Hengda fat coal & $\begin{array}{l}\text { Kowloon } \\
\text { coking coal }\end{array}$ & $\begin{array}{c}\text { Junteng } \\
\text { gas fat coal }\end{array}$ & $\begin{array}{l}\text { Luan meager } \\
\text { lean coal }\end{array}$ & $\begin{array}{c}\text { Luneng } \\
\text { bituminous } \\
\text { coal }\end{array}$ & $\begin{array}{l}\text { Lushi gas } \\
\text { fat coal }\end{array}$ \\
\hline$T_{\text {fixed carbon }}\left[{ }^{\circ} \mathrm{C}\right]$ & 566.66 & 577.96 & 589.30 & 569.91 & 560.00 & 590.59 & 539.64 & 529.64 \\
\hline & $\begin{array}{c}\text { meager lean } \\
\text { coal }\end{array}$ & $\begin{array}{c}\text { Shanjiao high } \\
\text { sulphur main } \\
\text { coke } 2.0\end{array}$ & $\begin{array}{c}\text { Shanjiao high } \\
\text { sulphur main } \\
\text { coke } 1.3\end{array}$ & $\begin{array}{l}\text { Urat main } \\
\text { coke }\end{array}$ & $\begin{array}{c}\text { Xielian } \\
\text { coking coal }\end{array}$ & $\begin{array}{l}\text { Sheep canal } \\
\text { river lean coal }\end{array}$ & raw coal & \\
\hline$T_{\text {fixed carbon }}\left[{ }^{\circ} \mathrm{C}\right]$ & 587.69 & 544.62 & 570.83 & 539.87 & 513.43 & 590.13 & 521.89 & \\
\hline
\end{tabular}

TABLEIV. THE VOLATILE AND FIXED CARBON COMBUSTION TEMPERATURE DIFFERENCE OF THE 15 KINDS OF BITUMINOUS COALS

\begin{tabular}{|c|c|c|c|c|c|c|c|c|}
\hline & $\begin{array}{l}\text { High sulphur } \\
\text { rich coal } 1.6\end{array}$ & $\begin{array}{c}\text { Domestic main } \\
\text { coke }\end{array}$ & Hengda fat coal & $\begin{array}{l}\text { Kowloon } \\
\text { coking coal }\end{array}$ & $\begin{array}{c}\text { Junteng } \\
\text { gas fat coal }\end{array}$ & $\begin{array}{l}\text { Luan meager } \\
\text { lean coal }\end{array}$ & $\begin{array}{c}\text { Luneng } \\
\text { bituminous } \\
\text { coal } \\
\end{array}$ & $\begin{array}{c}\text { Lushi gas } \\
\text { fat coal }\end{array}$ \\
\hline \multirow[t]{2}{*}{$\begin{array}{c}T_{\text {volatile matter }}-T_{\text {fixed }} \\
\text { carbon }\left[{ }^{\circ} \mathrm{C}\right] \\
\end{array}$} & 112.53 & 127.09 & 146.52 & 100.12 & 67.74 & 80.32 & 85.25 & 118.56 \\
\hline & $\begin{array}{c}\text { meager lean } \\
\text { coal }\end{array}$ & $\begin{array}{l}\text { Shanjiao high } \\
\text { sulphur main } \\
\text { coke } 2.0\end{array}$ & $\begin{array}{c}\text { Shanjiao high } \\
\text { sulphur main } \\
\text { coke } 1.3\end{array}$ & $\begin{array}{l}\text { Urat main } \\
\text { coke }\end{array}$ & $\begin{array}{c}\text { Xielian } \\
\text { coking coal }\end{array}$ & $\begin{array}{l}\text { Sheep canal } \\
\text { river lean coal }\end{array}$ & raw coal & \\
\hline $\begin{array}{c}T_{\text {volatile matter }}-T_{\text {fixed }} \\
\text { carbon }\left[{ }^{\circ} \mathrm{C}\right]\end{array}$ & 87.88 & 85.89 & 115.92 & 86.90 & 107.94 & 97.51 & 62.58 & \\
\hline
\end{tabular}

